\title{
RANCANG BANGUN GENERATOR AXIAL FLUX PERMANENT MAGNET (AFPM) MULTICAKRAM 1 FASA DENGAN KUTUB BERLAWANAN (N-S) MENGGUNAKAN MAGNET PERMANEN NEODYMIUM IRON BORON (NdFeB)
}

\author{
Pandu Putra Pratama*, Widyono Hadi, Widya Cahyadi \\ Jurusan Teknik Elektro, Fakultas Teknik, Universitas Jember \\ Jl. Kalimantan No.37 Kampus Bumi Tegal Boto Jember 68121 \\ *Penulis korespondensi, E-mail: pandugekos@gmail.com
}

\begin{abstract}
Abstrak
Generator Axial Flux Permanen Magnet (AFPM) merupakan generator yang mampu menghasilkan tegangan relatif tinggi dengan putaran rendah. Salah satunya adalah generator multicakram yang memiliki jumlah cakram stator dan cakram rotor lebih banyak dari generator tipe lainnya. Pada rancang bangun generator multicakram AC 1 fasa ini menggunakan magnet Neodyimium Iron Boron $(\mathrm{NdFeB})$ yang disusun dengan kutub berlawanan pada magnet yang berhadapan. Pengujian pertama diberikan putaran sebesar 3000 RPM pada generator dengan jumlah beban sebanyak 8 paralel yang disetiap paralel terdapat 7 LED terhubung seri. Diperoleh frekuensi gelombang output generator $400.6 \mathrm{~Hz}$, tegangan beban $14.65 \mathrm{~V}$, arus beban $13.704 \mathrm{~mA}$, daya $0.2008 \mathrm{~W}$, dan torsi $6.39 \times 10^{-4} \mathrm{Nm}$. Pengujian kedua, generator dihubungkan dengan full wave rectifier (penyearah gelombang penuh) yang selanjutnya dihubungkan dengan beban, menghasilkan frekuensi luaran rectifier $800 \mathrm{~Hz}$, tegangan beban $12.380 \mathrm{~V}$, arus beban $13.340 \mathrm{~mA}$, daya $0.161 \mathrm{~W}$, dan torsi $5.129 \times 10^{-4}$ $\mathrm{Nm}$. Pungujian ketiga ditambahkan kapasitor pada rectifier yang berfungsi untuk mengurangi tegangan ripple pada full wave rectifier, sehingga dihasilkan tegangan DC yang terhubung pada beban. Diperoleh tegangan beban $14.700 \mathrm{~V}$, arus beban $15.147 \mathrm{~mA}$, daya $0.223 \mathrm{~W}$, dan torsi $7.115 \times 10^{-4} \mathrm{Nm}$. Semakin besar jumlah beban pada generator maka tegangan semakin kecil, sedangkan arus, daya, dan torsi semakin besar.
\end{abstract}

Kata kunci: generator axial flux permanent magnet (AFPM), multicakram, 1 fasa

\begin{abstract}
Axial Flux Generator Permanent Magnet (AFPM) is a generator that is producing relatively high voltages with low rotation. One of them is a multi-disc generator which has more stator and rotor discs than other types. The design of this single phase $\mathrm{AC}$ multi-disc generator using Neodyimium Iron Boron $(\mathrm{NdFeB})$ magnets arranged with opposite poles on the opposite magnet. The first test is given a rotation of 3000 RPM on a generator with a total load of 8 parallel, each of which has 7 LEDs connected in series. The obtained generator output wave frequency is $400.6 \mathrm{~Hz}$, load voltage is 14.65 $\mathrm{V}$, load current is $13,704 \mathrm{~mA}$, power is $0.2008 \mathrm{~W}$, and torque is $6.39 \times 10^{-4} \mathrm{Nm}$. The second test, the generator is connected to a full wave rectifier (full wave rectifier) which is then connected to the load, the rectifier output frequency is $800 \mathrm{~Hz}$, the load voltage is $12,380 \mathrm{~V}$, the load current is $13,340 \mathrm{~mA}$, the power is $0.161 \mathrm{~W}$, and the torque is $5.129 \times 10^{-4} \mathrm{Nm}$. The third praise is to add a capacitor to the rectifier which functions to reduce the ripple voltage on the full wave rectifier, so that a DC voltage is connected to the load. Obtained a load voltage of $14,700 \mathrm{~V}$, a load current of $15,147 \mathrm{~mA}$, a power of $0.223 \mathrm{~W}$, and a torque of $7.115 \times 10^{-4} \mathrm{Nm}$. The greater the number of loads added, the smaller the voltage, while the current, power and torque are greater.
\end{abstract}

Keywords : permanent magnet axial flux generator (AFPM), multi-disk, 1 phase

\section{Pendahuluan}

Generator merupakan sebuah mesin listrik yang sering digunakan pada energi terbarukan sebagai pembangkit listrik. Generator listrik adalah suatu alat yang dapat mengubah suatu energi mekanik atau energi gerak menjadi suatu energi listrik dengan adanya proses induksi magnetik. Secara umum generator yang sering dijumpai merupakan sebuah generator dengan tipe High Speed, dimana dengan tipe high speed tersebut dibutuhkan energi mekanik yang cukup besar agar dapat menghasilkan tegangan [1].

Saat ini dibutuhkan generator yang dapat menghasilkan tegangan yang relatif tinggi dengan skala energi terbarukan yang relatif kecil. Generator tersebut adalah generator axial flux permanent magnet (AFPM). Beberapa jenis magnet digunakan untuk AFPM, antara lain menggunakan magnet array [2], magnet permanen khususnya dari bahan neodymium $(\mathrm{NdFeB})$ [3-7]. Selain 
itu beberapa studi telah dilakukan guna untuk memperoleh kinerja yang maksimum.

Pada penelitian sebelumnya, dirancang AFPM pada silikon dengan magnet NdBFe [5], namun kemampuan dayanya kecil. Selain itu, dilakukan rancang bangun generator $\mathrm{AC}$ konstruksi axial flux satu fasa menggunakan magnet NdFeB silinder dengan kutub magnet berlawanan (U-S) [6] maupun searah (U-U) [7]. Pada penelitian tersebut dilakukan pengujian dengan menggunakan beban resistor namun pengujian tersebut masih belum bisa memperlihatkan penggunaan dalam kehidupan sehari hari. Selain itu, pada penelitian tersebut generator memiliki konstruksi tipe single side.

Oleh karena itu, pada penelitan ini dilakukan dengan cara merancang generator AFPM Multicakram 1 fasa dengan jumlah stator sebanyak 3 dan jumlah rotor sebanyak 2 . Generator 1 fasa ini menggunakan magnet Neodymium Iron Boron $(\mathrm{NdFeB})$ yang disusun secara berlawanan $(\mathrm{N}$ $\mathrm{S})$. Target pada penelitian ini adalah dapat menghasilkan tegangan sebesar $15 \mathrm{~V}$ dan daya sebesar 5,5 Watt pada kecepatan putar sebesar $3000 \mathrm{rpm}$ dan akan diberikan beban berupa rangkaian LED.

\section{Metode}

\subsection{Konsep umum}

Generator AFPM Multicakram 1 Fasa ini membutuhkan energi mekanik yang diperoleh dari motor DC. Generator AFPM Multicakram ini terdiri dari 3 buah stator dan 2 buah rotor. Rotor tersebut diletakkan diantara stator.

Sebelum melakukan pengujian generator pada 2 kondisi dilakukan pengukuran kecepatan putar rotor dengan satuan radian per menit (RPM) dan diukur menggunakan tachometer. Hal tersbut dilakukan untuk menjaga kecepatan agar tetap disetiap kondisi. Pada pengujian dilakukan dalam 2 kondisi tak terbeban dan dengan terbeban, dimana pada kondisi terbeban dapat menggunakan rectifier dan tanpa rectifier. Oleh karena itu, pada kondisi menggunakan rectifier dapat menggunakan kapasitor dan tanpa kapasitor. Pengujian tersebut menggunakan rectifier digunakan untuk mengetahui hasil luaran DC sedangkan tanpa rectifier untuk luaran AC. Selain itu, pada pengujian luaran rectifier menggunakan kapasitor dan tidak bertujuan untuk mengetahui hasil luaran yang terbaik. Pengukuran tegangan dan arus menggunakan multimeter, sedangkan frekuensi dan gelombang pada pengujian menggunakan oskiloskop. Peta pengujian generator AFPM ditunjukkan pada Gambar 1.

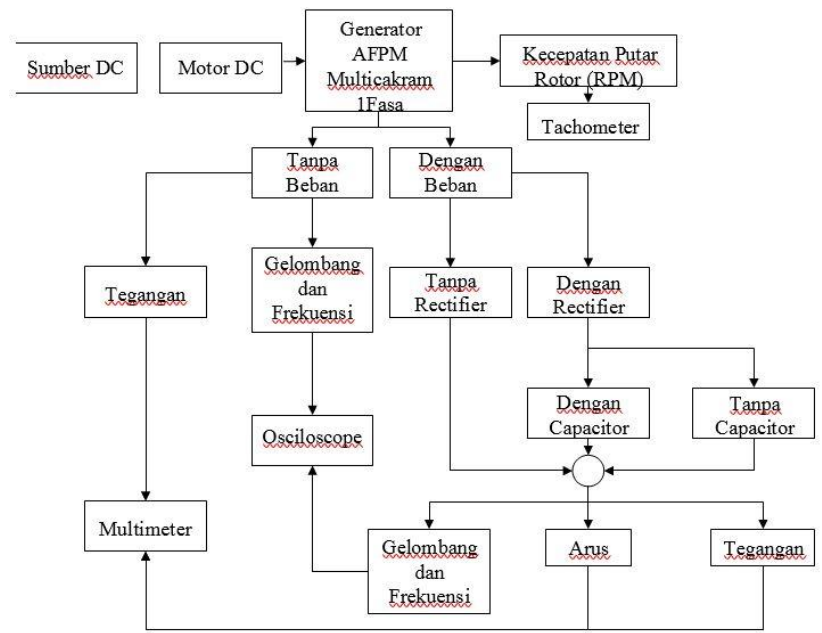

Gambar 1. Peta pengujian generator AFPM

\subsection{Perancangan Generator}

Sebelum dilakukan perancangan, berikut ini adalah spesifikasi perancangan dari generator AFPM Multicakram yang dapat dilihat pada Tabel 1.

Tabel 1. Spesifikasi Generator AFPM Multicakram

\begin{tabular}{|c|c|c|}
\hline Parameter & Simbol & Nilai \\
\hline Jumlah fasa & Nph & 1 fasa \\
\hline Jumlah stator & & 3 stator \\
\hline Jumlah rotor & & 2 rotor \\
\hline Jumlah kumparan & Ns & 8 kumparan \\
\hline Jumlah kumparan & $[\mathrm{Ns})]$ tot & 24 kumparan \\
\hline $\begin{array}{l}\text { Jumlah lilitan per } \\
\text { kumparan }\end{array}$ & $\mathrm{N}$ & 300 lilitan \\
\hline Inti Besi & & $\mathrm{Ya}$ \\
\hline Diameter kawat email & & $0.4 \mathrm{~mm}$ \\
\hline \multirow{2}{*}{ Ukuran Stator } & $p$ & $11 \mathrm{~cm}$ \\
\hline & I & $11 \mathrm{~cm}$ \\
\hline $\begin{array}{l}\text { Jumlah magnet per } \\
\text { rotor }\end{array}$ & $\mathrm{Nm}$ & 8 magnet \\
\hline \multirow[t]{2}{*}{ Dimensi magnet } & $r$ & $7.5 \mathrm{~mm}$ \\
\hline & t & $3 \mathrm{~mm}$ \\
\hline Diameter rotor & $\mathrm{D}$ & $9.5 \mathrm{~cm}$ \\
\hline Radius dalam magnet & r_i & $2.75 \mathrm{~cm}$ \\
\hline Radius luar magnet & r_o & $4.25 \mathrm{~cm}$ \\
\hline Jarak antar magnet & $T \_f$ & $1.256 \mathrm{~cm}$ \\
\hline
\end{tabular}

Pada perancangan rotor dilakukan perhitungan sebagai berikut.

\subsubsection{Perancangan Rotor}

Pada perancangan rotor dilakukan perhitungan sebagai berikut. 
a. Menentukan Jumlah Pole

Jika diketahui frekuensi dan kecepatan putar sebesar $50 \mathrm{~Hz}$ dan $375 \mathrm{rpm}$, maka diperoleh pole sebanyak 16 buah [2]

Dimana :

$$
p=120 . f / N
$$

$f:$ frekuensi $(\mathrm{Hz})$

$p$ : pole

$N$ : kecepatan putar (Rpm)

\section{b. Menentukan Fluks Maksimum}

Pada perancangan ini magnet yang digunakan adalah tipe $\mathrm{NdFeB}$, dimana magnet tersebut memiliki ukuran diameter $1.5 \mathrm{~cm}$ dan tebal $0.3 \mathrm{~cm}$. Selanjutnya dilakukan pengukuran fluks magnet sebagai berikut :

Jika diketahui bahwa densitas fluks magnent $1.5 \mathrm{mT}$, jarijari $0.75 \mathrm{~cm}$, dan celah udara $0.7 \mathrm{~mm}$. Sehingga diperoleh $B_{\text {max }} 4,5 \times 10^{-4} T$ dan $A_{\text {magnet }} 1,766 \times 10^{-4} \mathrm{~m}^{2}$ [8]

$$
\begin{aligned}
& B_{\text {max }}=B_{r} \frac{l m}{l m+\delta} \\
& A_{\text {magnet }}=\pi \cdot\left(r_{\text {magnet }}\right)^{2}
\end{aligned}
$$

Dimana :

$$
\begin{array}{ll}
B_{r} & : \text { densitas fluks magnet }(\mathrm{T}) \\
\operatorname{lm} & : \text { tinggi magnet }(\mathrm{m}) \\
\delta & : \text { lebar celah udara }(\mathrm{m}) \\
r_{\text {magnet }} & : \text { jari-jari magnet }(\mathrm{m})
\end{array}
$$

$$
\Phi_{\text {max }}=A_{\text {magn }} \cdot B_{\text {max }} \cdot m \cdot R(4)
$$

dimana:

$\Phi_{\max } \quad$ : fluks maksimum magnet $(\mathrm{Wb})$

$A_{\text {magn }} \quad$ luasan medan magnet (m2)

$B_{\max } \quad$ : kerapatan medan magnet maksimum (T)

$m \quad$ : jumlah Magnet

$R \quad$ : jumlah rotor

Dengan menggabungkan persamaan (2) dan (3) pada perrsamaan (4), maka diperoleh fluks maksimum pada 2 rotor sebesar $1,2717 \times 10^{-6} \mathrm{~Wb}$. Pengukuran fluks magnet ditunjukkan pada Gambar 2.

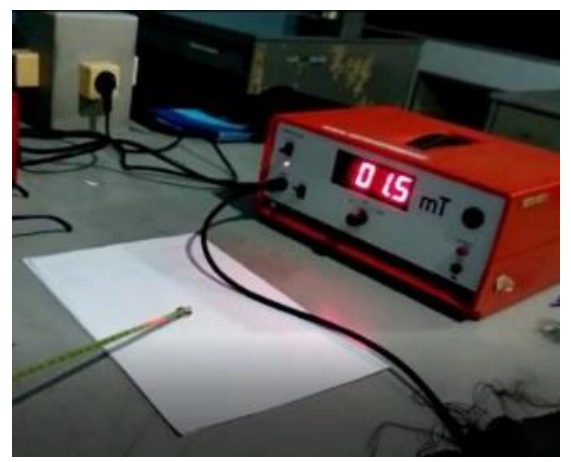

Gambar 2. Pengukuran Fluks Magnet

\subsubsection{Perancangan Stator}

Pada perancangan stator dilakukan perhitungan sebagai berikut.

\section{a. Menentukan Jumlah Kumparan}

Pada penentuan jumlah kumparan dapat diketahui dengan jumlah pole sebanyak 16, sehigga diperoleh jumlah kumparan sebanyak 8 dengan persamaan berikut [9]:

$$
N_{s}=p \cdot N_{p h} / 2
$$

dimana:

Ns : Jumlah kumparan

Nph : Jumlah fasa

p : pole

\section{b. Menentukan Diameter Kawat Email}

Dengan target tegangan sebesar $\pm 15 \mathrm{~V}$ dan daya sebesar $\pm 5,5$ Watt pada kecepatan putar sebesar $3000 \mathrm{rpm}$. Maka dengan persamaan dibawah ini diperoleh arus sebesar $0.3667 \mathrm{~A}$, dimana kawat email yang memiliki karakteristik dengan arus maksimum sebesar 0.3667 A adalah kawat email berdiameter $0.4 \mathrm{~mm}$.

$$
I=P V
$$

dimana: $I$ : Arus (A)

$P$ : Daya $(\mathrm{W})$

$V$ : Tegangan $(\mathrm{V})$

c. Menentukan Jumlah Lilitan

Dalam menentukan jumlah lilitan dilakukan perhitungan dengan persamaan berikut sehingga diperoleh jumlah lilitan sebanyak 300 lilitan.

$$
E_{a}=\frac{2 \pi}{\sqrt{2}} \cdot f \cdot N \cdot \Phi_{\max } \cdot N_{s} / N_{p h}(7)
$$

dimana:

Ea : tegangan efektif induksi generator (V)

$f \quad$ : frekuensi (Hz)

$N \quad$ : jumlah lilitan

$\Phi_{\max } \quad$ : fluks maksimum magnet $(\mathrm{Wb})$

$N_{s} \quad$ : Jumlah kumparan

$N_{p h} \quad$ : Jumlah fasa

\subsection{Desain Alat \\ 2.3.1. Desain Rotor}

Generator AFPM Multicakram 1 fasa ini terdiri dari 2 buah rotor, dimana masing-masing rotor terdapat 8 buah magnet Neodymium Iron Boron (NdFeB) silinder berdiameter 15 $\mathrm{mm}$ dan tebal $3 \mathrm{~mm}$ yang dipasang dengan kutub yang berlawanan $(\mathrm{N}-\mathrm{S})$. Jarak antara inti rotor dengan inti magnet adalah $3,5 \mathrm{~cm}$ dengan jarak antar magnet sebesar 
$45^{0}$ [8]. Desain rotor dua dimensi ditunjukkan pada Gambar 3. Selain itu, desain tiga dimensi (3D) rotor embedded dan pemasangan magnet ditunjukkan di Gambar 4.

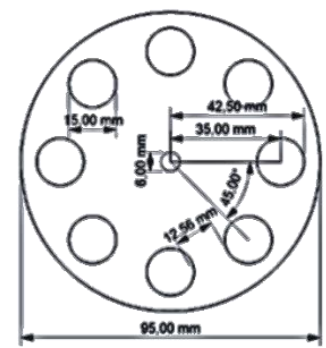

Gambar 3. Desain dua dimensi (2D) kerangka rotor

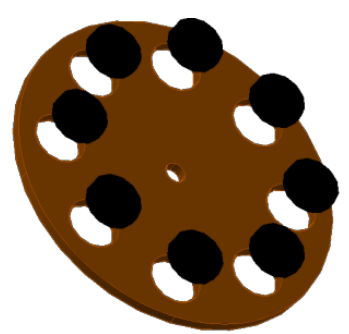

Gambar 4. Desain tiga dimensi (3D) rotor embedded dan pemasangan magnet

\subsubsection{Desain Stator}

Generator AFPM Multicakram 1 fasa ini dibuat dengan 3 buah stator, dimana masing-masing stator terdapat 8 buah kumparan yang terdiri dari 300 lilitan. Kawat email yang digunakan berukuran $0.4 \mathrm{~mm}$. Kemudian kawat email tersebut dililitkan pada spull plastik dan diletakkan pada akrilik dengan ukuran $11 \mathrm{~cm} \times 11 \mathrm{~cm} \times 0.5 \mathrm{~cm}$. Desain dari kerangka stator ditunjukkan di Gambar 5.

Dengan jumlah kumparan pada setiap rotor sebanyak 8 maka diletakannya kumparan pada kerangaka stator yaitu dengan sudut antara kumparan 1 dengan kumparan lainnya sebesar $45^{\circ}[8]$. desain dari peletakan kumparan ditunjukkan di Gambar 6.

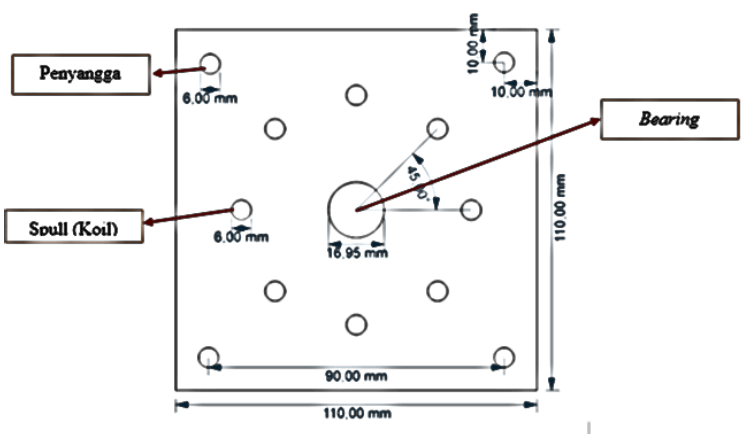

Gambar 5. Desain dua dimensi (2D) kerangka stator

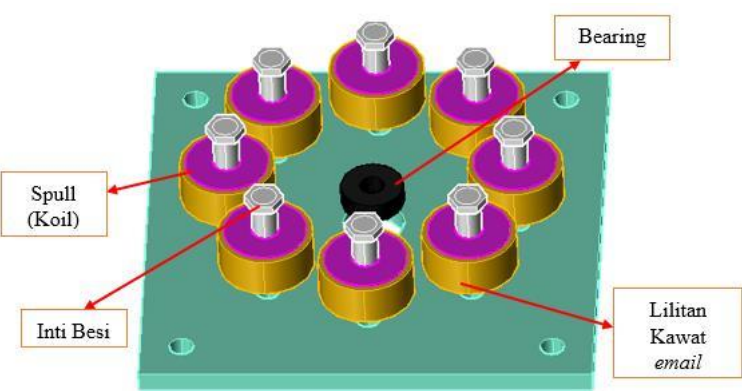

Gambar 6. Desain tiga dimensi (3D) stator

\subsubsection{Desain Generator AFPM Multicakram 1 Fasa}

Stator dan rotor dirakit sedemikian rupa untuk menjadi generator AFPM Multicakram, dimana konstruksi dari generator tersebut dapat dilihat pada gambar 7 .

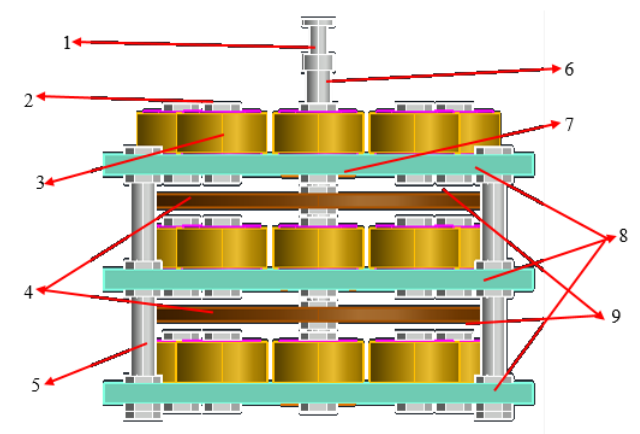

Gambar 7. Desain tiga dimensi (3D) Generator AFPM Multicakram 1 Fasa

Keterangan :
1. Pulley
6. Shaft
2. Inti Besi
7. Bearing
3. Kumparan (Coil)
8. Stator
4. Rotor
9. Air Gap
5. Penyangga

\subsection{Metode Pengumpulan Data \\ 2.4.1. Pengujian}

Pengumpulan data pengujian dilakukan dalam 2 kondisi tak terbeban dan dengan terbeban, dimana pada kondisi terbeban dapat menggunakan rectifier dan tanpa rectifier, dimana pada kondisi menggunakan rectifier dapat menggunakan kapasitor dan tanpa kapasitor. Pengujian dengan beban dihubungkan dengan LED yang disusun hingga 8 paralel yang disetiap paralel terdapat 7 LED seri.

\section{Pengujian tanpa beban}

Pengujian ini dilakukan pada kecepatan putar tetap 3000 rpm yang dilakukan pada 2 kondisi yaitu pada luaran AC dan luaran rectifier. Pengujian ini dilakukan untuk mengetahui frekuensi dan tegangan open circuit (Voc). 


\section{Pengujian dengan beban}

Pengujian ini dilakukan pada kecepatan yang sama yaitu 3000 rpm, dimana pada kondisi terbeban dapat menggunakan rectifier dan tanpa rectifier. Pada kondisi menggunakan rectifier dapat menggunakan kapasitor dan tanpa kapasitor. Pengujian dengan beban dihubungkan dengan LED yang disusun hingga 8 paralel yang disetiap paralel terdapat 7 LED seri. Pada pengujian ini diperoleh tegangan dan arus sehingga diperoleh daya dan torsi.

\section{Hasil dan Pembahasan}

\subsection{Rancang Bangun Generator AFPM Multicakram 1 Fasa}

\section{Pembuatan Rotor}

Pada pembuatan rotor magnet dipasang akrilik dengan ketebalan $0.3 \mathrm{~cm}$. Rotor pada gambar 8 dibuat sebanyak 2 buah[10].

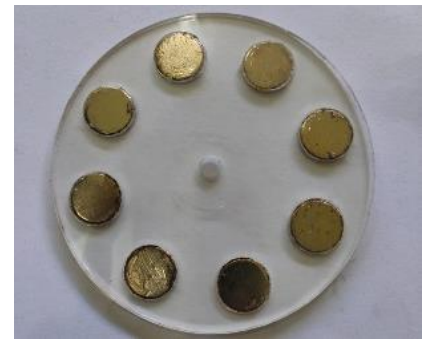

\section{Gambar 8. Rotor Generator AFPM}

\section{Pembuatan Stator}

Pada pembuatan stator terdapat kumparan yang yang dipasang pada kerangka stator dan di tengah kerangka terdapat bearing yang direkatkan menggunakan lem. Pembuatan stator dibuat sebanyak 3 buah seperti gambar 9 .

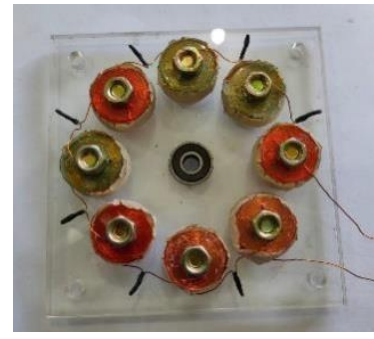

Gambar 9. Stator Generator AFPM

\section{Pembuatan Generator AFPM Multicakram}

Pada pembuatan generator, stator dan rotor dihubungkan dengan sebuah shaft berdiameter $\pm 0.6 \mathrm{~cm}$ dan rotor berada diantara stator dengan jarak celah $0.7 \mathrm{~cm}$. Gambar 10 menunjukkan pembuatan generator.

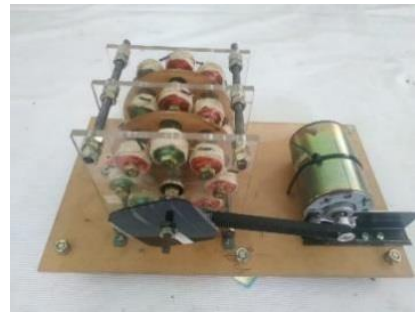

\section{Gambar 10. Generator AFPM}

Pada generator dlakukan pengukuran sehingga diperoleh induksi kumparan (L) $42.5 \mathrm{mH}$, densitas fluks magnet $(\mathrm{Br})$ $1.5 \mathrm{mT}$, dan resistansi jangkar (Ra) $50.97 \Omega$.

\subsection{Pengujian Generator AFPM Multicakram 1 Fasa Dengan Variasi Beban LED \\ 3.2.1. Pengujian Tanpa Beban}

\section{Pengujian pada Luaran AC}

Pada pengujian ini dilakukan pada putaran yang tetap sebesar $3000 \mathrm{rpm}$. Sehingga diperoleh tegangan, gelombang dan frekuensi seperti ditunjukkan pada Tabel 2.

Tabel 2. Data hasil pengujian tanpa beban luaran AC

\begin{tabular}{lll}
\hline Kecepatan $(\mathrm{rpm})$ & $\operatorname{Voc} \boldsymbol{A C}(\mathrm{V})$ & Frekuensi $(\mathrm{Hz})$ \\
\hline 3000 & 15.870 & 400.6 \\
\hline
\end{tabular}

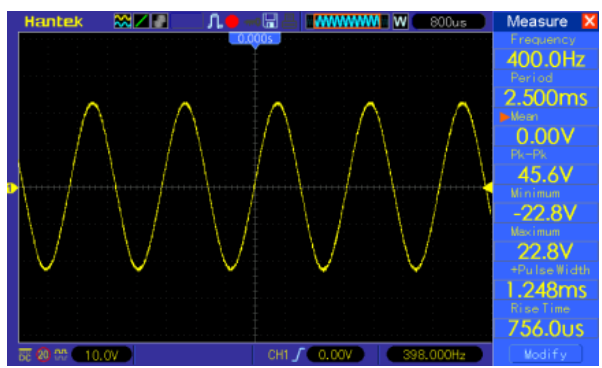

Gambar 11. Frekuensi Gelombang Luaran AC

Pada pengujian ini generator tidak terhubung oleh beban sehingga diperoleh tegangan open circuit $15.87 \mathrm{~V}$ dengan frekuensi $400.6 \mathrm{~Hz}$ dan kecepatan 3000, seperti ditunjukkan pada Gambar 11. Pada pengujian ini sudah sesuai dengan perancangan yaitu dapat mengahasilkan tegangan hingga $15 \mathrm{~V}$ pada putaran dan frekuensi tersebut.

\section{Pengujian pada Luaran Rectifier}

Pada pengujian ini dilakukan pada putaran yang tetap sebesar $3000 \mathrm{rpm}$, dimana luaran dari generator ini dihubungkan dengan full bridge rectifier. Sehingga diperoleh tegangan, gelombang dan frekuensi seperti ditunjukkan pada Tabel 3 dan Gambar 12. 
Tabel 3. Data hasil pengujian tanpa beban luaran rectifier

\begin{tabular}{lllll}
\hline $\begin{array}{l}\text { Kecepatan } \\
(\mathrm{rpm})\end{array}$ & $\begin{array}{l}\text { Frekuensi } \\
\text { AC }(\mathrm{Hz})\end{array}$ & VocAC $(\mathrm{V})$ & $\begin{array}{l}\text { Frekuensi } \\
\text { Rectifier } \\
(\mathbf{H z})\end{array}$ & $\boldsymbol{V o s}(\mathrm{V})$ \\
\hline 3000 & 400,6 & 15,870 & 798,7 & 14,24 \\
\hline
\end{tabular}

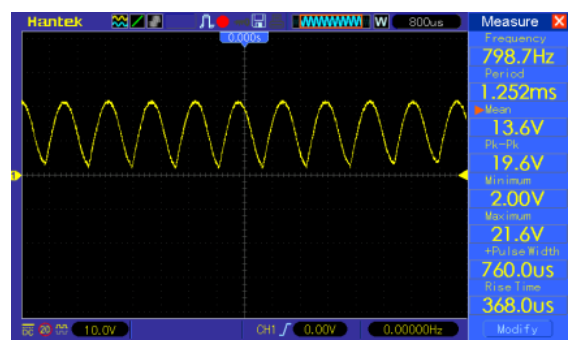

Gambar 12. Frekuensi Gelombang Luaran AC

\subsubsection{Pengujian Dengan Beban}

Pada pengujian dengan beban dilakukan dengan menggunakan LED yang dipasang paralel hingga 8, dimana disetiap paralel terdapat 7 buah LED seri. Berikut ini adalah pengujian menggunakan beban :

\section{Pengujian pada luaran AC}

Tabel 4. Data Hasil Pengujian Generator pada Luaran AC saat Diberikan Variasi Beban Paralel

\begin{tabular}{ccccc}
\hline $\begin{array}{c}\text { Kecepatan } \\
(\mathrm{rpm})\end{array}$ & $\begin{array}{c}\text { Frekuensi } \\
(\mathrm{Hz})\end{array}$ & $\begin{array}{c}\text { Jumlah } \\
\text { Paralel }\end{array}$ & $\begin{array}{c}\text { Tegangan } \\
\text { Output AC } \\
(\mathbf{V})\end{array}$ & $\begin{array}{c}\text { Arus } \\
\text { Output AC } \\
(\mathbf{m A})\end{array}$ \\
\hline & & 1 & 15,100 & 10,533 \\
& & 2 & 14,940 & 11,571 \\
3000 & 3 & 14,890 & 12,426 \\
& 400,6 & 4 & 14,840 & 12,698 \\
& & 5 & 14,730 & 13,010 \\
& & 6 & 14,710 & 13,330 \\
& 7 & 14,680 & 13,650 \\
& 8 & 14,650 & 13,704 \\
\hline
\end{tabular}

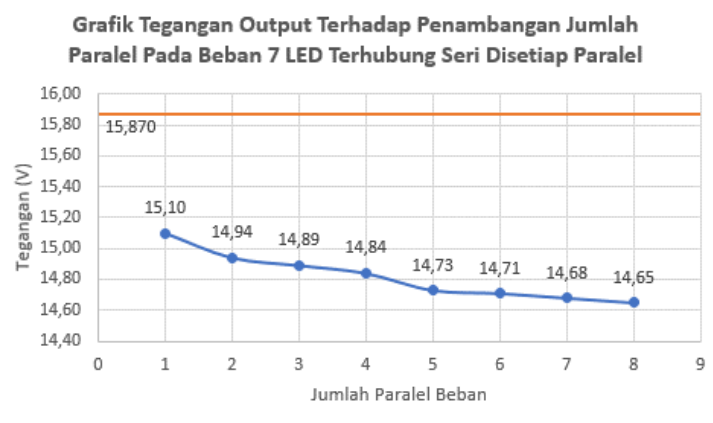

—Teganagan Beban Luaran AC — Tegangan Open Circuit AC

Gambar 13. Grafik Tegangan Output Terhadap Penambahan Jumlah Paralel Pada Beban 7 LED Terhubung Seri Disetiap Paralel
Tabel 4 menunjukkan hasil pengujian saat terbebani pada luaran AC. Berdasarkan tabel 4, semakin banyak jumlah beban paralel yang digunakan, maka tegangan yang dihasilkan akan semakin kecil. Hal tersebut diakibatkan karena adanya drop tegangan yang semakin besar seiring bertambahnya beban.

Sementara itu, Gambar 13 menunjukkan grafik tegangan output terhadap penambahan jumlah paralel pada beban 7 LED terhubung seri di setiap paralel. Semakin besarnya drop tegangan dari tegangan open circuit, karena semakin besarnya rugi rugi kumparan yang dihasilkan.

\section{Grafik Arus Output Terhadap Penambangan Jumlah Paralel Pada Beban 7 LED Terhubung Seri Disetiap Paralel}

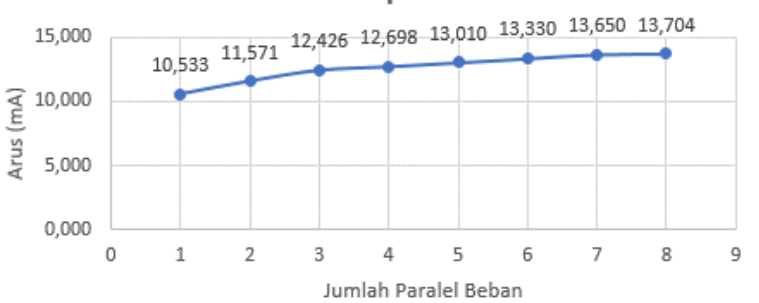

Gambar 14. Grafik Arus Output Terhadap Penambahan Jumlah Paralel Pada Beban 7 LED Terhubung Seri Di Setiap Paralel.

Gambar 14 menunjukkan grafik arus output terhadap penambahan jumlah paralel pada beban 7 LED terhubung seri di setiap paralel. Sebagaimana persamaan rugi-rugi kumparan, semakin besar arus yang terukur, maka semakin besar pula drop tegangan yang terjadi. Selain itu semakin banyak jumlah beban paralel yang digunakan, maka arus yang terukur juga semakin besar.

Semakin banyak jumlah beban paralel yang digunakan, maka daya yang dihasilkan akan semakin besar. Selain itu daya mempengaruhi besar torsi putar dengan semakin besar daya yang dihasilkan maka torsi juga semakin besar. Tabel 5 dan Gambar 15-16 menunjukkan data terkait.

Tabel 5. Data Hasil Perhitungan Generator pada Luaran AC saat Diberikan Variasi Beban Paralel

\begin{tabular}{cccc}
\hline $\begin{array}{c}\text { Kecepatan } \\
(\mathbf{r p m})\end{array}$ & $\begin{array}{c}\text { Jumlah Paralel } \\
\text { Beban }\end{array}$ & $\boldsymbol{P A C}$ (Watt) & Torsi (Nm) \\
\hline & 1 & 0,1583 & $5.04 \times 10^{-4}$ \\
& 2 & 0,1725 & $5.49 \times 10^{-4}$ \\
3 & 0,1839 & $5.85 \times 10^{-4}$ \\
3000 & 4 & 0,1876 & $5.97 \times 10^{-4}$ \\
& 5 & 0,1917 & $6.1 \times 10^{-4}$ \\
& 6 & 0,1959 & $6.23 \times 10^{-4}$ \\
& 7 & 0,2001 & $6.37 \times 10^{-4}$ \\
& 8 & 0,2008 & $6.39 \times 10^{-4}$ \\
\hline
\end{tabular}




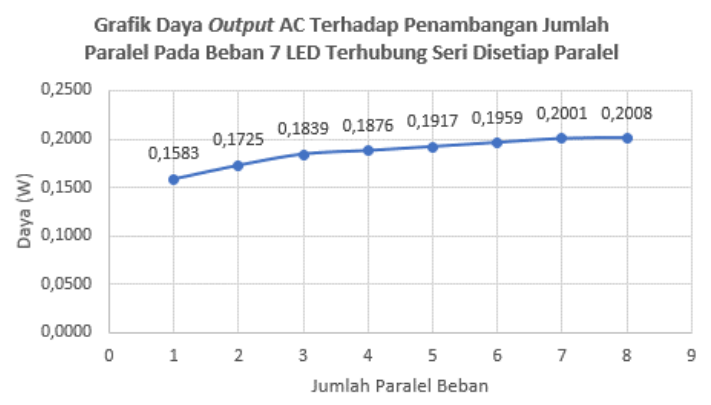

Gambar 15. Grafik Daya Output Terhadap Penambahan Jumlah Paralel Pada Beban 7 LED Terhubung Seri Disetiap Paralel

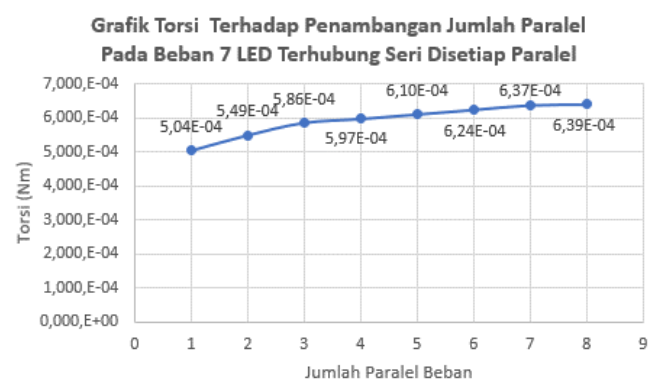

Gambar 16. Grafik Torsi Terhadap Penambahan Jumlah Paralel Pada Beban 7 LED Terhubung Seri Disetiap Paralel

\section{Pengujian pada luaran Rectifier}

Pada pengujian dengan beban dilakukan dengan menggunakan LED pengujian yang sama, namun keluaran dari generator dihubung terlebih dahulu menuju full bridge rectifier tanpa filter. Tabel 6 menunjukkan hasil pengukuran pada saat diberikan beban. Berdasarkan tabel tersebut, dapat dikatakan bahwa tegangan akan semakin kecil dan arus akan semakin besar seiring bertambahnya jumlah beban paralel. Selain itu tegangan pada luaran rectifier lebih kecil dari luaran AC, dimana hal tersebut diakibatkan karena adanya drop tegangan pada dioda bridge.

Tabel 6. Data Hasil Pengujian Generator pada Luaran Rectifier saat Diberikan Variasi Beban Paralel

\begin{tabular}{ccccc}
\hline $\begin{array}{c}\text { Kecepatan } \\
\text { (rpm) }\end{array}$ & $\begin{array}{c}\text { Jumlah } \\
\text { Paralel } \\
\text { Beban }\end{array}$ & $\begin{array}{c}\text { Frekuensi } \\
\text { (Hz) }\end{array}$ & $\begin{array}{c}\text { Tegangan } \\
\text { Output (V) }\end{array}$ & $\begin{array}{c}\text { Arus } \\
\text { Output } \\
(\mathbf{m A})\end{array}$ \\
\hline & 1 & & 13,249 & 9,374 \\
& 2 & & 12,835 & 10,760 \\
3000 & 3 & & 12,712 & 11,464 \\
& 4 & \multirow{2}{*}{801,20} & 12,595 & 12,120 \\
& 5 & & 12,526 & 12,571 \\
& 6 & & 12,460 & 12,701 \\
& 7 & & 12,415 & 12,827 \\
& 8 & & 12,380 & 13,340 \\
\hline
\end{tabular}

Gambar 17 dan 18 menunjukkan grafik tegangan dan arus output terhadap penambahan jumlah parallel pada beban 7 LED terhubung seri di setiap parallel.

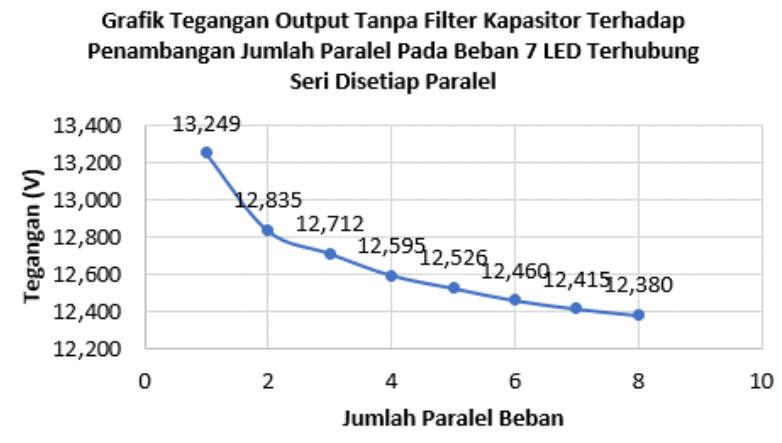

Gambar 17. Grafik Tegangan Output Terhadap Penambahan Jumlah Paralel Pada Beban 7 LED Terhubung Seri Disetiap Paralel

Grafik Arus Output RectifierTanpa Filter Kapasitor Terhadap Penambangan Jumlah Paralel Pada Beban 7 LED Terhubung Seri Disetiap Paralel

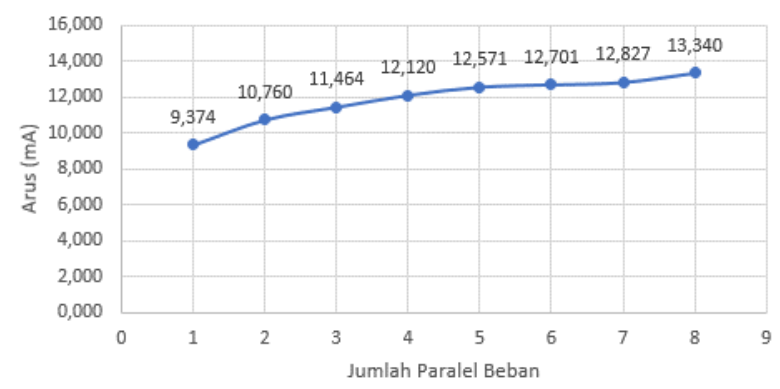

Gambar 18. Grafik Arus Output Terhadap Penambahan Jumlah Paralel Pada Beban 7 LED Terhubung Seri Disetiap Paralel

Tabel 7. Data Hasil Perhitungan Generator pada Luaran Rectifier saat Diberikan Variasi Beban Paralel

\begin{tabular}{cccc}
\hline $\begin{array}{c}\text { Kecepatan } \\
(\mathbf{r p m})\end{array}$ & $\begin{array}{c}\text { Jumlah } \\
\text { Paralel } \\
\text { Beba }\end{array}$ & Po(W) & Torsi (Nm) \\
\hline & 1 & 0,118 & $3.744 \times 10^{-4}$ \\
& 2 & 0,134 & $4.259 \times 10^{-4}$ \\
3000 & 3 & 0,141 & $4.491 \times 10^{-4}$ \\
& 4 & 0,148 & $4.718 \times 10^{-4}$ \\
& 5 & 0,153 & $4.876 \times 10^{-4}$ \\
& 6 & 0,154 & $4.912 \times 10^{-4}$ \\
& 7 & 0,155 & $4.948 \times 10^{-4}$ \\
& 8 & 0,161 & $5.129 \times 10^{-4}$ \\
\hline
\end{tabular}

Pada hasil perhitungan yang ditunjukkan pada Tabel 7, daya berbanding lurus dengan tegangan dan arus, sehingga dengan semakin banyak jumlah beban yang digunakan maka daya yang dihasilkan semakin besar. Selain itu, torsi akan semakin besar jika daya yang dihasilkan generator semakin besar [11]. Grafik daya dan torsi terkait ditunjukkan di Gambar 18 dan 19. 


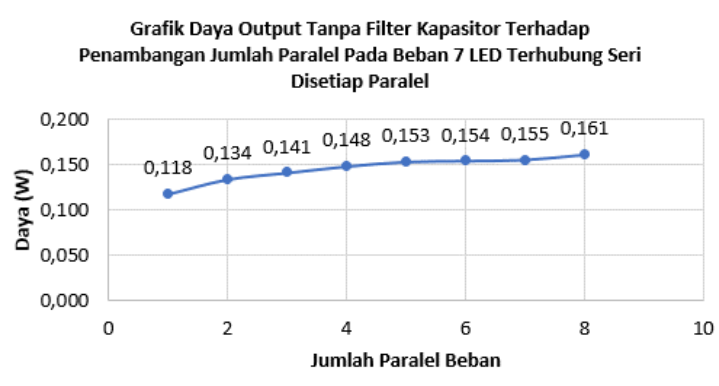

Gambar 18. Grafik Daya Output Terhadap Penambahan Jumlah Paralel Pada Beban 7 LED Terhubung Seri Disetiap Paralel

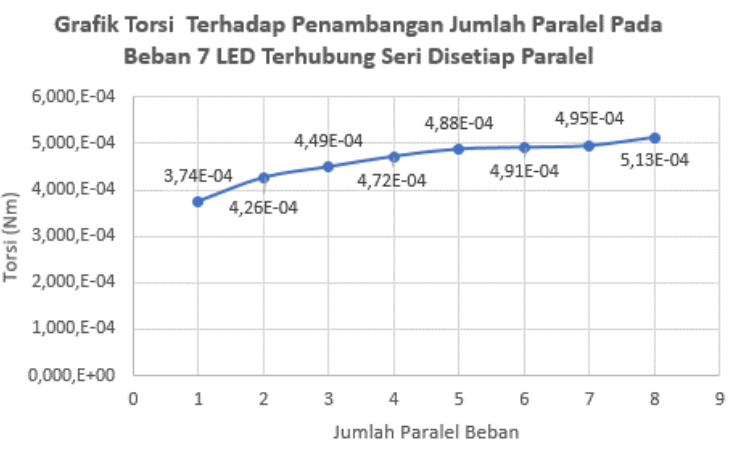

Gambar 20. Grafik Torsi Output Terhadap Penambahan Jumlah Paralel Pada Beban 7 LED Terhubung Seri Disetiap Paralel

3. Pengujian pada luaran DC

Pada pengujian ini generator dihubungkan dengan rectifier dengan ukuran $1000 \mathrm{uF}$ menggunakan perhitungan [12-15] dan diperoleh hasil seperti tabel 8. Penggunaan kapasitor pada pengujian ini untuk memperoleh luaran DC yang baik. Dengan menggunakan filter kapassitor diperoleh Tabel 9.

Tabel 8. Data Tabel Penentuan Kapasitor Sebagai Filter Pada Full Bridge Rectifier

\begin{tabular}{ccccc}
\hline $\mathbf{r}(\%)$ & $\begin{array}{c}\text { Resistansi } \\
\text { Beban } \\
\text { Paralel } \mathbf{8}(\boldsymbol{\Omega})\end{array}$ & $\begin{array}{c}\text { Frekuensi } \\
\text { AC } \\
(\mathrm{Hz})\end{array}$ & $\begin{array}{c}\text { Kapasitor } \\
\text { Terhitung } \\
(\mathrm{uF})\end{array}$ & $\begin{array}{c}\text { Kapasitor } \\
\text { yang } \\
\text { Digunakan (uF) }\end{array}$ \\
\hline 0,05 & 928,036 & 400,6 & 776,486 & 1000 \\
\hline
\end{tabular}

Tabel 9. Data Hasil Pengujian Generator pada Luaran DC saat Diberikan Variasi Beban Paralel

\begin{tabular}{ccccccc}
\hline $\begin{array}{c}\text { Kecepatan } \\
\text { (rpm) }\end{array}$ & $\begin{array}{c}\text { Frekuensi } \\
\text { AC (Hz) }\end{array}$ & $\begin{array}{c}\text { Jumlah } \\
\text { Beban } \\
\text { Paralel }\end{array}$ & $\begin{array}{c}\text { VoAC } \\
\text { (V) }\end{array}$ & $\begin{array}{c}\text { IoAC } \\
\text { (mA) }\end{array}$ & $\begin{array}{c}\text { VoDC } \\
\text { (V) }\end{array}$ & $\begin{array}{c}\text { IoDC } \\
\text { (mA) }\end{array}$ \\
\hline & & 1 & 15,471 & 13,882 & 15,777 & 11,840 \\
& & 2 & 15,263 & 15,625 & 15,392 & 12,620 \\
\multirow{3}{*}{3000} & \multirow{2}{*}{400,6} & 4 & 15,175 & 16,380 & 15,203 & 13,210 \\
& & 5 & 15,089 & 16,955 & 15,022 & 14,345 \\
& & 6 & 14,050 & 17,325 & 14,930 & 14,754 \\
& & 7 & 14,984 & 17,590 & 14,822 & 15,022 \\
& & 8 & 14,974 & 17,860 & 14,807 & 15,089 \\
& & & & & & \\
\hline
\end{tabular}

Grafik Tegangan Output DC dengan Filter Kapasitor $1000 \mathrm{uF}$ Terhadap Penambangan Jumlah Paralel Pada Beban 7 LED Terhubung Seri Disetiap Paralel

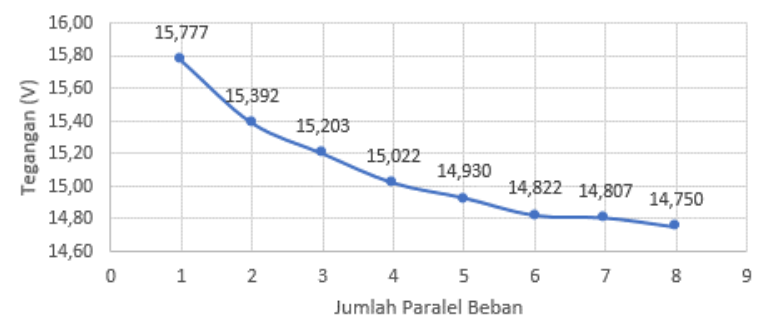

Gambar 21. Grafik Tegangan Luaran DC Terhadap Penambahan Jumlah Paralel Pada Beban 7 LED Terhubung Seri Disetiap Paralel

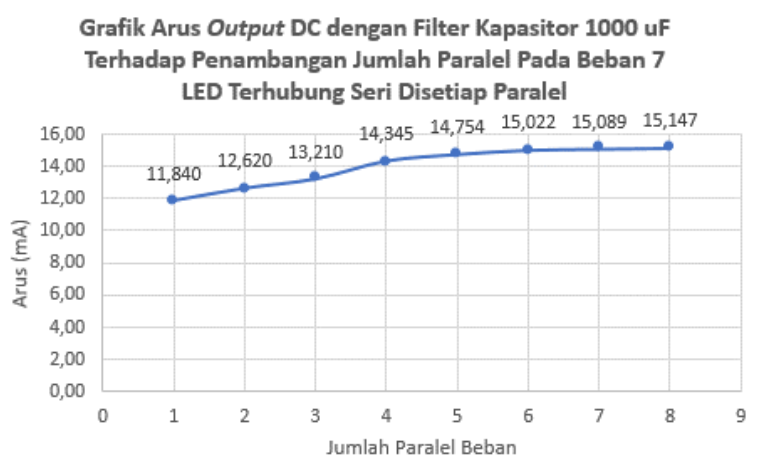

Gambar 22. Grafik Arus Luaran DC Terhadap Penambahan Jumlah Paralel Pada Beban 7 LED Terhubung Seri Disetiap Paralel

Sama seperti pengujian sebelumnya, tegangan pada pengujian ini semakin menurun dan arus semakin meningkat seperti pada Gambar 21 dan 22, namun pada pengujian ini tegangan luaran DC lebih besar dari tegangan sebelum sebelumnya, karena terdapat sebuah kapasitor.

Tabel 10. Data Hasil Perbandingan Ripple Factor Dengan Tegangan Luaran DC

\begin{tabular}{cccc}
\hline Kecepatan & $\begin{array}{c}\text { Jumlah } \\
\text { Beban }\end{array}$ & $\begin{array}{c}\text { Ripple } \\
\text { Factor }\end{array}$ & VoDC ukur (V) \\
\hline \multirow{3}{*}{3000} & 1 & 0,00027 & 15,777 \\
& 2 & 0,00029 & 15,392 \\
& 3 & 0,00031 & 15,203 \\
& 4 & 0,00034 & 15,022 \\
& 5 & 0,00035 & 14,930 \\
& 6 & 0,00036 & 14,822 \\
& 7 & 0,00036 & 14,807 \\
& 8 & 0,00037 & 14,750 \\
\hline
\end{tabular}

Dari data di Tabel 10, dapat dilihat bahwa tegangan akan semakin kecil dan ripple factor yang dihasilkan akan semakin besar seiring bertambahnya jumlah beban dengan menggunakan kapasitor pada rangkaian rectifier sebesar 1000 uF. Grafik ripple ditunjukkan pada Gambar 23. 


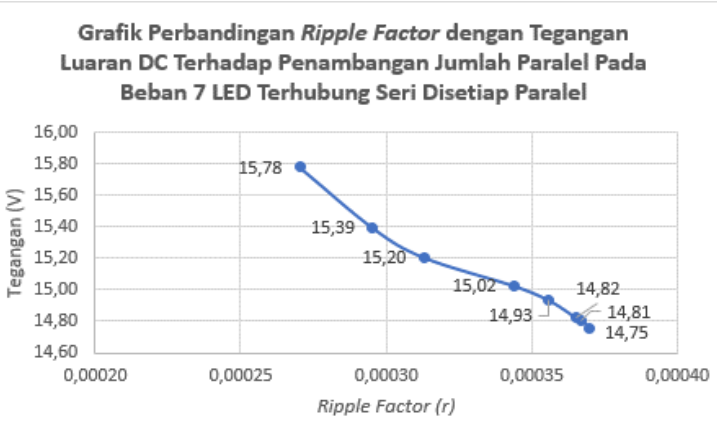

Gambar 23. Grafik Perbandingan Ripple Factor dengan Tegangan Luaran DC Penambahan Jumlah Paralel Pada Beban 7 LED Terhubung Seri Disetiap Paralel

Tabel 11. Data Hasil Perhitungan Generator pada Luaran DC saat Diberikan Variasi Beban Parale

\begin{tabular}{cccc}
\hline $\begin{array}{c}\text { Kecepatan } \\
(\mathbf{r p m})\end{array}$ & $\begin{array}{c}\text { Jumlah } \\
\text { Paralel } \\
\text { Beban }\end{array}$ & Po (W) & Torsi (Nm) \\
\hline & 1 & 0,187 & $5.949 \times 10^{-4}$ \\
& 2 & 0,194 & $6.186 \times 10^{-4}$ \\
3000 & 3 & 0,201 & $6.395 \times 10^{-4}$ \\
& 4 & 0,215 & $6.862 \times 10^{-4}$ \\
& 5 & 0,220 & $7.015 \times 10^{-4}$ \\
& 6 & 0,223 & $7.091 \times 10^{-4}$ \\
& 7 & 0,223 & $7.115 \times 10^{-4}$ \\
& 8 & 0,223 & $7.115 \times 10^{-4}$ \\
\hline
\end{tabular}

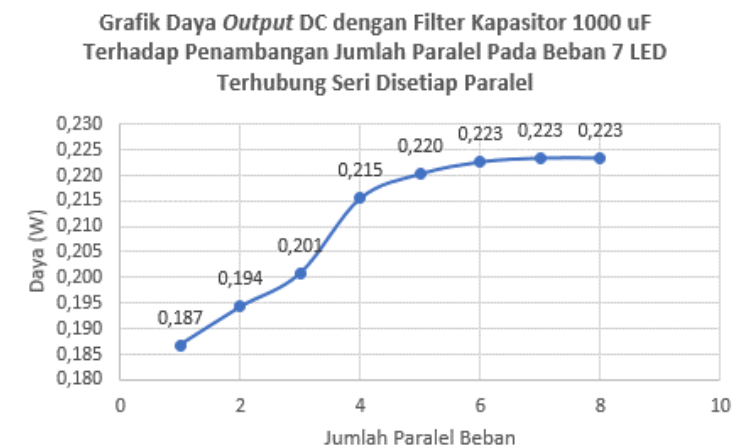

Gambar 24. Grafik Daya Luaran DC Terhadap Penambahan Jumlah Paralel Pada Beban 7 LED Terhubung Seri Disetiap Paralel

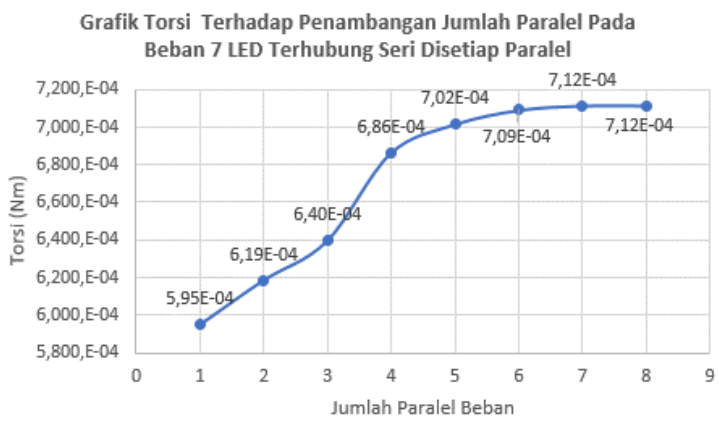

Gambar 25. Grafik Torsi Terhadap Penambangan Jumlah Paralel Pada Beban 7 LED Terhubung Seri Disetiap Paralel
Dari data daya dan torsi di Tabel 11 dan Gambar 24-25 tersebut dapat diketahui bahwa daya dan torsi yang diperoleh semakin meningkat seiring bertambahnya beban.

\section{Kesimpulan}

Generator AFPM Multicakram 1 fasa dengan kutub berlwanan (N-S) menggunakan magnet Neodymium Iron Boron $(\mathrm{NdFeB})$. Pada generator ini terdiri dari 3 buah stator dengan 24 kumparan disetiap stator, dan 300 lilitan dengan kawat email berdiameter $0.4 \mathrm{~mm}$ disetiap kumparan. Selain itu generator ini terdiri dari 2 buah rotor, dimana terdapat 8 buah magnet disetiap rotornya. Dengan putaran $3000 \mathrm{rpm}$ diperoleh tegangan open circuit AC dan rectifier sebesar $15.870 \mathrm{~V}$ dan $14.24 \mathrm{~V}$, sedangkan frekuensi luaran AC dan rectifier sebesar $400 \mathrm{~Hz}$, dan 800 Hz. Dengan melakukan pengujian menggunakan beban dengan jumlah paralel 8 diperoleh tegangan $14.650 \mathrm{~V}$, arus $13.704 \mathrm{~mA}$, daya $0.2008 \mathrm{~W}$, dan torsi $6.39 \times 10-4 \mathrm{Nm}$. Dari pengujian ini diharapkan dapat dilakukan pengujian dengan memperhatikan rugi-rugi lainnya, selain itu konstruksi penunjang perlu diperhatikan guna untuk menghasilkan performa yang maksimum. Dari pengujian tersebut dapat dikatakan bahwa perancangan generator ini sudah sesuai dengan apa yang

diharapkan yaitu dapat menghasilkan tegangan $15 \mathrm{~V}$ pada putaran dan frekuensi yang tetap yaitu $400 \mathrm{~Hz}$ untuk luaran generator sendiri (tanpa diberi beban). Sedangkan hasil daya yang dirancang untuk generator ini sendiri masih belum memenuhi harapan karena penggunaan beban LED yang mengakibatkan daya yang dihasilkan relative kecil.

\section{Referensi}

[1]. J. F. Gieras, R.-J. Wang, and M. J.Kamper, Axial Flux Permanent Magnet Brushless Machines, 2nd Edition. Springer Science \& Business Media, 2008.

[2]. A. Habib, H. S. Che, N. Abd Rahim, M. Tousizadeh, and E. Sulaiman, "A fully coreless Multi-Stator Multi- Rotor (MSMR) AFPM generator with combination of conventional and Halbach magnet arrays," Alexandria Eng. J., vol. 59, no. 2, pp. 589-600, 2020, doi: 10.1016/j.aej.2020.01.039.

[3]. Chan, T. F., and L. L. Lai. "An axial-flux permanentmagnet synchronous generator for a direct-coupled windturbine system." IEEE Transactions on Energy Conversion 22, no. 1 (2007): 86-94.

[4]. Bumby, J. R., and Richard Martin. "Axial-flux permanent-magnet air-cored generator for small-scale wind turbines." IEE Proceedings-Electric Power Applications 152, no. 5 (2005): 1065-1075.

[5]. Holmes, Andrew S., Guodong Hong, and Keith R. Pullen. "Axial-flux permanent magnet machines for micropower generation." Journal of microelectromechanical systems 14, no. 1 (2005): 54-62.

[6]. Rohmah, Ainur. "Rancang Bangun Generator AC Konstruksi Axial Flux Satu Fasa Menggunakan Magnet Neodymium (NdFeB) Silinder Dengan Kutub Magnet Berlawanan (US)." Disertasi PhD, Fakultas Teknik Uiversitas Negeri Jember, 2019. 
[7]. Karisma Addina Putri, Alysa. "Rancang Bangun Generator Axial Flux Satu Fasa Menggunakan Neodymium Iron Boron Magnet (Ndfeb) Silinder Dengan Kutub Searah (UU)." Disertasi PhD., Fakultas Teknik Universitas Jember, 2019

[8]. S. J. Chapman, Electric Machinery Fundamentals, 4th ed. Australia: McGraw - Hill Companies, 2005.

[9]. W. Budi Pramono, Warindi, and A. Hidayat, "Perancangan mini generator turbin angin $200 \mathrm{~W}$ untuk energi angin kecepatan rendah," Pros. Snatif, vol. 4, no. 1, pp. 374-382, 2010.

[10]. Puja, Setia, and P. Rozeff. "Rancang Bangun Mini Generatoe Fluks Aksial 1 Fasa Putaran Rendah Menggunakan Neodymium Magnet $(\mathrm{NdFeB})$ Berbasis Multi Cakram." FT. UMRAH, p. 117, 2017.

[11]. Sumiati, Ruzita, and Aidil Zamri. "Rancang bangun miniatur turbin angin pembangkit listrik untuk media pembelajaran." Jurnal Teknik Mesin (JTM) 3, no. 2 (2013)
[12]. A. Atmam, "Penggunaan Filter Kapasitif Pada Rectifier Satu Phasa Dan Tiga Phasa Menggunakan Power Simulator (Psim)," SainETIn, vol. 2, no. 1, pp. 18-26, 2018, doi: 10.31849/sainetin.v2i1.1667.

[13]. Giyantara, Andhika, Vicky Mudeng, Rizky Ramadhani, and Rizky Wulandari. "Analisis Rangkaian Full Wave Rectifier dengan Filter Kapasitor, Pembagi Tegangan, Buffer dan Penguat Differensial pada Sensor Arus." SPECTA Journal of Technology 3, no. 2 (2019): 1-9.

[14]. Sedra, Microelectronic Circuits, 7th ed. Wiley, 2017

[15]. Harianto, Totok, and Yanu Shalahuddin. "Filter Pasif Single Tuned LC sebagai Kompensator Harmonisa Pada Beban Listrik Rumah Tangga Menggunakan Matlab Simulink." Setrum: Sistem Kendali-Tenaga-elektronikatelekomunikasi-komputer 7, no. 1 (2018): 127-135. 